\title{
PERAN MASYARAKAT DALAM PENCEGAHAN DAN PENANGGULANGAN TERHADAP PENYALAHGUNAAN DAN PEREDARAN GELAP NARKOTIKA
}

\author{
Gunawan Antiprawiro \\ gun_prawiro@yahoo.co.id \\ Pusat Penelitian dan Pengembangan Kesejahteraan Sosial, \\ Badan Pendidikan dan Penelitian, Kementerian Sosial RI, Jakarta
}

\begin{abstract}
The purpose of this research is to understand the peoples' response toward rampaging of narcotic misuse in Yogyakarta and the existence of peoples' participation of Yogyakarta. Based on descriptive analysis of data collection through some techniques of (a) documentation study, (b) in-depth interview, (c) observation and (d) focused group discussion (FGD) it is explored that peoples' participation has functioned as social energy and has developed as a social movement. Values which is rooted from various resources like religions, ethics and regulation are the important determinant and binding the people's behavior to achieve success in the implementation of P4GN (Prevention and Elimination of Illegal Circulation and Misuse of Narcotics). This social movement also shows consistency and responsibility of the Republic of Indonesia as a state toward the ASEAN agreement and nations in the world to fight against misuse and illegal circulation of narcotics. The agreement of ASEAN has provided great opportunity for the youth and student in the ASEAN's countries to exchange information, to do comparative study and workshop among the young generation for the implementation of P4GN.
\end{abstract}

Keywords: People's role, Elimination, Misuse Narcotics

\section{Abstrak}

Tujuan penelitian ini adalah untuk mengetahui respon masyarakat terhadap maraknya penyalahgunaan narkotika di Yogyakarta, dan eksistensi partisipasi masyarakat Yogyakarta. Dari analisis deskriptif terhadap data yang dihimpun dengan teknik : (a) studi dokumentasi, (b) wawancara mendalam, (c) observasi, dan (d) diskusi kelompok terarah (FGD) terungkap bahwa partisipasi masyarakat telah berfungsi sebagai energi sosial dan berkembang sebagai suatu gerakan sosial. Nilai dari berbagai agama, etika, serta Peraturan Perundangan merupakan determinan penting dan mengikat perilaku masyarakat untuk mencapai keberhasilan penyelengaraan P4GN. Gerakan sosial ini menunjukkan konsistensi dan pertanggungjawaban Negara Republik Indonesia atas kesepakatan ASEAN dan bangsa bangsa dunia dalam memerangi penyalahgunaan dan peredaran gelap narkotika. Kesepakatan Komunitas ASEAN memberikan peluang besar bagi pemuda dan mahasiswa di negara negara ASEAN untuk saling tukar informasi, studi banding, dan workshop antar pemuda dan mahasiswa dalam penyelenggaraan P4GN.

Kata Kunci: Peran Masyarakat,

Penanggulangan, Penyalahgunaan Narkotika

\section{Fenomena Ancaman Narkotika}

Di bidang kesehatan, berbagai penemuan bahan dan jenis narkotika telah memberikan kontribusi besar untuk pengobatan. Narkotika, psikhotropika, dan zat adiktif lainnya 
(Napza) merupakan bahan yang semakin penting dan dibutuhkan untuk pelayanan kesehatan bagi negara di dunia. Ditinjau dari perkembangan ilmu dan teknologi (farmakologi), telah banyak ditemukan berbagai tanaman dan bukan tanaman yang dapat dijadikan sebagai bahan narkotika, bentuk kemasan, dan pemanfaatannya. Dari catatan Simanungkalit (2011:31), obat menjadi unsur paling penting dan digunakan secara terus menerus dalam setiap kebudayaan, evolusi sosial, ekonomi, kesehatan dan spiritual, dan hanya empat dari 237 negara yang tidak memiliki catatan penggunaan zat memabukkan.

Secara yuridis, eksistensi narkotika telah mendapat legitimasi di Indonesia. Dalam Undang Undang Nomor 35 Tahun 2009 tentang Narkotika Pasal 4 disebutkan, bahwa Undang Undang tentang Narkotika bertujuan (a) Menjamin ketersediaan Narkotika untuk kepentingan pelayanan kesehatan dan/atau pengembangan ilmu pengetahuan dan teknologi (iptek); (b) Mencegah, melindungi, dan menyelamatkan bangsa Indonesia dari penyalahgunaan Narkotika; (c) Memberantas peredaran gelap Narkotika dan Perkursor Narkotika; dan (d) Menjamin pengaturan upaya rehabilitasi medis dan sosial bagi penyalahguna dan pecandu narkotika. Dalam Pasal 7 ditegaskan bahwa Narkotika hanya dapat digunakan untuk kepentingan pelayanan kesehatan dan/atau pengembangan ilmu pengetahuan dan teknologi. Ketentuan ini dapat diinterpretasikan, bahwa Narkotika merupakan barang yang harus ada dan hanya untuk kepentingan sangat terbatas. Jika barang tersebut dipergunakan untuk kepentingan diluar kepentingan kesehatan dan pengembangan iptek, maka dapat dikategorikan sebagai melanggar hukum atau penyalahgunaan narkotika.

Sejak diberlakukannya Undang Undang No 35/2009 tentang Narkotika, Undang-Undang Nomor 22 Tahun 1997 tentang Narkotika dan Undang-Undang Nomor 5 Tahun 1997 tentang Psikotropika telah dicabut dan dinyatakan tidak berlaku. Jenis psikotropika dan zat adiktif lainnya dijadikan sebagai bagian dari Narkotika. Dalam Pasal 153 huruf b UU No 35/2009 disebutkan Lampiran mengenai jenis Psikotropika Golongan I dan Golongan II sebagaimana tercantum dalam Lampiran Undang-Undang Nomor 5 Tahun 1997 tentang Psikotropika (Lembaran Negara Republik Indonesia Tahun 1997 Nomor 10, Tambahan Lembaran Negara Republik Indonesia Nomor 3671) yang telah dipindahkan menjadi Narkotika Golongan I. Penjelasan dalam Pasal 1 Bab 1 UU No. 35/2009 yang dimaksud dengan Narkotika adalah zat atau obat yang berasal dari tanaman atau bukan tanaman, baik sintetis maupun semisintetis, yang dapat menyebabkan penurunan atau perubahan kesadaran, hilangnya rasa, mengurangi sampai menghilangkan rasa nyeri, dan dapat menimbulkan ketergantungan, yang dibedakan ke dalam golongan-golongan sebagaimana terlampir dalam Undang-Undang ini. Dalam pasal 6 UU no 35/2009, penggolongan narkotika dibagi dalam tiga golongan yakni (a) Narkotika Golongan I $(65$ jenis); (b) Narkotika Golongan II (86 jenis); dan (c) Narkotika Golongan III (14 jenis). Khusus untuk narkotika golongan I, penggunaannya diatur dalam pasal 12 ayat (1). Narkotika Golongan I dilarang diproduksi dan/atau digunakan dalam proses produksi, kecuali dalam jumlah yang sangat terbatas untuk kepentingan pengembangan di bidang kesehatan serta ilmu pengetahuan dan teknologi. 
Sisi lain dari hasil pengembangan kesehatan dan iptek tersebut adalah narkotika telah dijadikan sebagai salah satu sasaran eksploitasi bisnis gelap (black market) untuk memperoleh keuntungan besar tanpa menghiraukan dampak yang ditimbulkan bagi manusia. Keberadaan narkotika telah menyumbang meningkatnya korban penyalahgunaan dan peredaran gelap narkotika. Dalam Pasal 1 Angka 15 UU 35/ 2009 dijelaskan bahwa Penyalah Guna adalah orang yang menggunakan Narkotika tanpa hak atau melawan hukum.

Di dunia perdagangan gelap narkotika, Indonesia mempunyai posisi strategis yakni berada di antara dua benua dan dua samudra. Keuntungan dari posisi geografis ini adalah semua negara di dunia mempunyai berbagai kepentingan terhadap Indonesia. Dari aspek ekonomi, Indonesia merupakan salah satu rute perdagangan internasional bahkan pangsa internasional, namun dari kepentingan perdagangan dunia tersebut tidak menutup kemungkinan terjadinya dampak negatif seperti peredaran gelap narkotika. Indonesia berdekatan dengan wilayah the Golden Triangle atau segitiga emas negara pusat produksi, penyelundupan dan perdagangan narkotika terbesar di AsiaTenggara. The Golden Triangle beranggotakan Thailand, Myanmar dan Laos. Negara di kawasan Asia Tenggara termasuk Indonesia merupakan negara tujuan The Golden Triangle. Kondisi ini tentunya dapat berpengaruh besar terhadap perdagangan ilegal dan korban penyalahgunaan narkotika di Indonesia.

Dinamika perkembangan
peredaran dan penyalahgunaan
Narkotika di Indonesia akhir akhir ini
semakin marak. Peredaran narkotika
dilakukan dengan teknologi canggih
dan telah merambah seluruh Indonesia.
Jenis psikotropika tidak lagi diimpor

namun pengedar lebih memilih membuat pabrik untuk memproduksi sendiri. Pengadaan bahan baku, peracikan, hingga perekrutan orang terkait pembagian tugas dalam memproduksi napza benar-benar direncanakan dengan baik. Ironisnya, peredaran narkotika juga dilakukan di lokasi yang dijaga sangat ketat seperti di lembaga pemasyarakatan, dimana narapidana bebas bertransaksi yang melibatkan oknum petugas, bahkan bisnis narkotika juga dikendalikan di rumah tahanan tersebut. Sebagai ilustrasi, sekitar 3,6 ton bahan dasar narkotika cair dikemas dalam 21 drum disita Badan Narkotika Provinsi Banten pada Kamis 18 Desember 2008. Diduga, zat kimia yang tergolong prekursor itu didatangkan secara gelap dari luar negeri melalui jalan laut. Bahan kimia cair dikemas dalam 21 drum. (Kompas.com, 2008). Sabtu tanggal 18 Mei 2013, Badan Narkotika Nasional (BNN) mengungkap pabrik gelap pembuatan narkotika (clandestine lab) di kawasan Kalideres, Jakarta Barat. Irjen Benny Mamoto mengemukakan "Mereka sengaja memilih lokasi yang orang tidak kira. Dari tempat pengeledahan, kami menyita mesin ekstasi, serbuk narkotika 2.445 gram dan 85 butir pil ekstasi, kasus ini pun akan dikembangkan dengan cara mengebon seorang nara pidana dari Lapas Cipinang. (Tribunnews.com, 2013). Bisnis narkotika sangat menguntungkan. Omset seminggu perdagangan narkotika di Indonesia mencapai Rp 100 miliar atau Rp 4,8 triliun setahun. Sebagian besar nilai omset tersebut dipasok oleh produsen narkotika dalam negeri (Simanungkalit, 2011:216).

Obyek yang dijadikan sasaran pengedar adalah setiap orang tanpa mengenal strata sosial, batas waktu dan tempat dimana narkotika akan diedarkan. Narkotika akan menyentuh 
dan merambah seluruh lapisan masyarakat, mulai pelajar, mahasiswa, kalangan profesional, selebritas, akademisi, anggota legislatif maupun eksekutif, aparat penegak hukum (oknum Polri-TNI), maupun atlet olahraga. Penyalahgunaan narkotika tidak hanya berakibat buruk pada kondisi fisik, mental dan sosial bagi korban, tetapi termasuk sosial dan ekonomi keluarga, kesehatan (HIV, Aids, Hepatitis C serta TBC), penurunan sumber daya manusia. Kondisi tentang produksi, peredaran, dan jumlah korban penyalahgunaan narkotika di atas tentunya akan (1) memberikan peluang besar (kemudahan) bagi seseorang untuk mendapatkan narkotika baik secara legal maupun gelap dan (2) upaya penanggulangan pencegahan penyalah gunaan napza semakin sulit.

\begin{tabular}{lrr}
\multicolumn{1}{c}{ Peredaran } & gelap & dan \\
penyalahgunaan & narkotika telah \\
dijadikan sebagai & isu krusial dan \\
menjadi ancaman bagi negara sejak \\
empat dekade. Keseriusan bangsa \\
dalam
\end{tabular}
penyalahgunaan narkotika ini tercermin dari Instruksi Presiden Republik Indonesia (Inpres) Nomor 6 Tahun 1971 kepada Kepala Badan Koordinasi Intelligen Nasional (BAKIN) untuk menanggulangi 6 (enam) permasalahan nasional yang menonjol, yaitu pemberantasan uang palsu, penanggulangan penyalahgunaan narkoba, penanggulangan penyelundupan, penanggulangan kenakalan remaja, penanggulangan subversi, dan pengawasan orang asing.

Tindakan pencegahan merupakan salah satu upaya penting dalam pengurangan resiko hasil inovasi bidang narkotika bagi masyarakat. Secara konseptual, pencegahan merupakan suatu upaya untuk menghindarkan terjadinya sesuatu yang tidak dikehendaki. Dari ketentuan hukum yang terkait dengan narkotika yang ada, aktor utama dalam pencegahan penyalahgunaan dan peredaran gelap narkotika, pada prinsipnya terdiri dari 3 kelompok, yakni pemerintah (public sector); lembaga usaha (Privat sector), dan masyarakat (collective action sector). Dalam peraturan ini, masyarakat mempunyai posisi strategik dan berpotensi besar dalam pencegahan penyalahgunaan dan peredaran gelap narkotika. Peran serta masyarakat sebagaimana termaktub dalam UU No 35/2009 Pasal 104, Masyarakat mempunyai kesempatan yang seluasluasnya untuk berperan serta membantu pencegahan dan pemberantasan penyalahgunaan dan peredaran gelap Narkotika dan Prekursor Narkotika; Pasal 105 Masyarakat mempunyai hak dan tanggung jawab dalam upaya pencegahan dan pemberantasan penyalahgunaan dan peredaran gelap Narkotika dan Prekursor Narkotika; dan pasal 107, Masyarakat dapat melaporkan kepada pejabat yang berwenang atau BNN jika mengetahui adanya penyalahgunaan atau peredaran gelap Narkotika dan Prekursor Narkotika. Ketentuan hukum ini mengisyaratkan, bahwa masyarakat turut bertangung jawab dalam pencapaian keberhasilan pencegahan penyalahgunaan dan peredaran gelap narkotila.

Dalam kerangka merespon maraknya peredaran gelap narkotika dan jumlah korban penyalahgunaan narkotika yang semakin meningkat, pemerintah membentuk Badan yang secara khusus mengurus tentang Narkotika dan dukungan dari instansi sektoral. Bagi pemerintah sudah ada kejelasan tentang program, sumber anggaran, dan personil serta fasilitas yang diperlukan. Persoalannya adalah bagaimana respon masyarakat terhadap maraknya penyalahgunaan narkotika di 
Yogyakarta, dan bagaimana eksistensi partisipasi masyarakat Yogyakarta tersebut bagi masyarakat, negara dan internasional. Akurasi dari jawaban atas pertanyaan tersebut tentunya diperlukan data dan informasi yang dihimpun dari beberapa sumber informasi. Pengumpulan data dan informasi dilakukan dengan teknik : (a) studi dokumentasi, (b) wawancara mendalam, (c) observasi, dan (d) diskusi kelompok terarah (FGD). Data yang terhimpun melalui penelitian ini akan dianalisis secara kualitatif menggunakan metode deskriptif. Dalam kerangka analisis ini tidak hanya terbatas pada pengumpulan dan penyusunan data, tetapi meliputi analisis dan interpretasi tentang arti data tersebut.

\section{Keberadaan Narkotika di Yogyakarta}

Di Yogyakarta, narkotika telah dikenal oleh masyarakat ratusan tahun yang lalu. Masyarakat menyebut dengan istilah Candu atau istilah lain Madat, Apiun, Opium. Catatan mengenai keberadan dan penggunaan candu di Indonesia baru diketahui pada akhir abad ke-16 dan awal abad ke-17 oleh J.C Boud dan candu mulai menyebar ke beberapa daerah di kepulauan Indonesia pada akhir tahun 1600. Daerah-daerah yang pertama kali didatangi para pedagang candu adalah daerah pelabuhan seperti Banten, Aceh, dan pelabuhan lada. Sementara itu, di daerah pedalaman yang banyak dijumpai perdagangan candu adalah daerah yang banyak dihuni oleh orang timur asing seperti Cina dan orang orang kaya. (Ibrahim, 2013:67)

Candu atau Madat atau Bunga opium (Papaver somniferum) yang sering disebut poppy merupakan salah satu bahan morphin. Candu pernah merebak pada abad 16-17 di Jawa. Dalam kurun waktu 180 tahun (1619 - 1799) VOC telah mengimpor dan memperdagangkan 10.080 ton opium mentah ke Jawa atau sekitar $56.000 \mathrm{~kg}$ opium mentah per tahun. Opium masuk secara luas khususnya di daerah pantura Jawa dengan sederet pelabuhannya serta di Kasunanan Surakarta dan Kasultanan Yogyakarta yang padat penduduknya. Di Yogyakarta saja, pada 1820, terdapat 372 tempat penjualan madat resmi yang mendapatkan lisensi dari pemegang monopoli, seperti pos dan sub pos bea cukai, serta pasar di Kasultanan Yogyakarta. (Garrybaldhi, 2013).

Dalam sejarah perkembangan narkotika, Yogyakarta pernah mempunyai posisi penting untuk pengelolaan dan peredaran candu. Di Indonesia terdapat tiga kantor pengelola candu, yakni: (1) Kantor Regi Candu dan Garam di Kediri; (2) Kantor Besar Regi Candu dan Garam di Surakarta dan (3) Kantor Depot Regi Candu dan Obat di Yogyakarta. Pabrik tempat pengolahan candu yang dikelola oleh pemerintah terletak di Wonosari Gunung Kidul dan Beji Klaten. Persediaan Candu setengah matang di pabrik Wonosari pada bulan November 1948 sebanyak tiga ton, sedangkan di pabrik Beji satu ton (Ibrahim, 2013). Ilustrasi tersebut mengindikasikan bahwa masyarakat Yogyakarta pada tahun 1950-an, umumnya telah mengenal narkotika.

Meskipun industri pengelolaan candu pada saat ini tinggal kenangan, namun peredaran narkotika di Daerah IstimewaYogyakarta (DIY) masih cukup tinggi, bahkan angka prevalensi penyalahgunaan narkotika di DIY sangat tinggi. Pada tahun 2010 DIY berada pada peringkat ke-2 di Indonesia setelah DKI Jakarta. Pada tahun 2013, peringkat DIY menurun pada posisi ke5. Meskipun telah terjadi penurunan peringkat, namun dilihat dari jumlahnya masih tergolong besar. Sebagai ilustrasi, data Badan Narkotika 
Provinsi DIY yang disampaikan pada Deklarasi Gerakan Anti Narkoba Nasional (Gannas) oleh wakil Ketua Gannas DIY (Sabtu tanggal 23 Januari 2010), DIY saat ini menduduki peringkat kedua tingkat penyalahgunaan narkoba di bawah DKI Jakarta dengan jumlah pemakai 68.980 orang (Kompas, 2010). Pada tahun 2013 angka penyalahgunaan narkotika mengalami peningkatan. Kondisi ini tercermin dari data Data BNN yang dibacakan Staf Ahli Gubernur DIY Agus Supriyono yang menyampaikan bahwa di DIY penyalahgunaan narkoba mencapai 87.473 orang. "DIY masuk prevalensi pengguna narkoba urutan lima besar di Indonesia," ujar Agus saat membacakan sambutan gubernur DIY dalam peringatan Hari Anti Narkotika Internasional tahun 2013 di halaman Balaikota Yogyakarta. Dalam proyeksi 2011-2015, berdasar kenaikan 0,12 persen pertahun dari penelitian 20082011, diprediksikan tahun 2014 pengguna narkoba DIY mencapai 97.432 orang. Sementara tahun 2015 mencapai 109.675 orang, atau 3,37 persen dari jumlah penduduk DIY (Sujatmiko, 2013).

Tingginya peredaran narkotika ini diduga mempunyai keterkaitan dengan tingginya mobilitas penduduk di Yogyakarta. Mobilitas penduduk tersebut tercermin dari banyaknya pelajar (masuk dan keluar), wisatawan (baik domestik maupun asing) yang berkunjung di kota tersebut. Beberapa titik rawan penyalahgunaan napza yang perlu dijadikan perhatian dalam pengawasan, yakni (1) wilayah yang bersinggungan dengan kampus; (2) tempat-tempat hiburan dan (3) wilayah perbatasan antara kota dengan kabupaten. Menurut Ketua RBM Gerhana di Meguwoharjo Kabupaten Sleman, salah satu titik yang dipandang rawan Napsa adalah daerah yang bersinggungan dengan kampus khususnya tempat kos. Indekos masih menjadi favorit peredaran narkoba sebab dinilai lebih aman. Tentang kondisi lingkungan kampus ini Kepala Bidang Pemberantasan Badan Narkotika Nasional Provinsi (BNNP) DIY, AKBP Sumargiyono di Jogja, Kamis (26/9/2013), mengatakan "Untuk kasus narkoba, kos-kosan masih dianggap aman dari pada di tempat-tempat hiburan malam". (JIBI, 2013). Meskipun lingkungan kampus dipandang rawan, namun tingginya kontrol sosial masyarakat ini masih diperhitungkan sebagai salah satu kekuatan untuk menghambat laju peredaran napsa.

Di wilayah perbatasan antara Kabupaten dan Kota dapat dijumpai kasus narkoba di Desa Selogedong, Argodadi Sedayu Kabupaten Bantul. Wilayah Selogedong berbatasan dengan Kabupaten Kulon Progo dan tidak jauh dengan batas kota Yogyakarta. Menurut Kadri (Ketua RBM Bariton), Selogedong pernah mendapat cap sebagai kampung merah, artinya banyak pemuda kampung yang selalu mengkonsumsi Minuman Keras (Miras). Meskipun sebagian besar yang dikonsumsi masyarakat masih dalam bentuk minuman keras (miras) namun perilakunya selalu mengganggu ketertiban, jika ada keramaian atau pertunjukan hiburan selalu membuat keonaran.

\section{Refleksi Sosial: Kepedulian Masyarakat dalam P4GN}
Kepedulian
masyarakat terhadap bahaya penyalahgunaan narkotika, pada dasarnya telah dimulai sekitar puluhan abad yang lalu. Dalam Simanungkalit (2011) sekitar abad 11 Masehi, iklan dan kampanye sistematis terhadap penyalahgunaan ganja dan opium telah dimulai. Hal ini berkaitan dengan bangkitnya agama agama monoteistik. Berkaitan dengan otoritas agama, dimulai dari daerah Muslim dan 
meluas ke daerah Kristiani pada abad ke 13. Mereka berpandangan bahwa pengunaan zat psikoaktif dikutuk sebagai jalan pintas. Untuk sebuah "Negara Tuhan", otoritas agama harus dipelihara, dan dapat dicapai hanya melalui puasa dan doa, atau meditasi. Mabuk dan penggunaan narkoba diasumsikan sebagai bentuk dari penyimpangan, pemberontakan dan klenik.

Di Indonesia khususnya di Jawa, kepedulian masyarakat terhadap bahaya narkotika sudah dilakukan sejak abad ke-17 di Surakarta. Merajalelanya penggunaan candu di Surakarta mendapat kecaman keras tidak hanya dari kaum muslim ortodoks, tetapi juga dari orang-orang Jawa aliran etika dan tradisional (Ibrahim, 2013). Penolakan penggunaan (menghisap, meminum) candu oleh masyarakat Muslim didasarkan pada filosofi bahwa candu adalah barang haram untuk dikonsumsi. Sri Susuhunan Paku Buwono IV mengecam penggunaan candu yang dituangkan dalam syair didaktik panjangnya yaitu Wulang Reh. Menghisap candu (madat) dianggap bagian dari molimo ${ }^{1}$ (lima larangan yang tidak boleh dilakukan).

Diskursus tentang wulang reh di lingkungan masyarakat Jawa hingga sekarang ini masih berjalan terutama di lingkungan keluarga. Meskipun informasi yang disampaikan hanya

\footnotetext{
${ }^{1}$ Wulang Reh adalah ajaran moral untuk pengendalian dalam berperilaku hidup harmoni atau menuju kesempurnaan hidup. Larangan yang cukup dikenal oleh masyarakat Jawa khususnya Yogyakarta adalah Molimo. Molimo adalah inisial huruf Mo (Jawa) atau M (latin) dan limo adalah menunjuk pada angka/jumlah sebanyak lima, artinya Lima $\mathrm{M}$ yang dijadikan larangan yakni, (1) Minum minuman keras: (2) Madat yakni menggunakan madat/candu dengan cara menghisap, meminum dan lain-lain; (3) Madon yakni main perempuan; (4) Main atau judi; dan (5) Maling atau mencuri.
}

sebatas apa yang dimaksud dengan molimo, namun secara eksplisit setiap anak dapat melengkapi informasi ini dengan informasi yang disajikan media cetak dan elektronik, baik informasi tentang bahaya, dampak, dan perlakuan (masyarakat maupun pemerintah) dalam memberikan sanksi kepada penyalahguna narkotika. Kondisi ini mengisyaratkan, bahwa eksistensi dari ajaran masyarakat Jawa tentang larangan Molimo, hingga sekarang tetap dimengerti oleh masyarakat luas (tidak hanya masyarakat di Surakarta, tetapi masyarakat Jawa pada umumnya).

Di lingkungan masyarakat Jawa, Wulang Reh berfungsi sebagai stimulus (rangsangan dan/atau dorongan untuk berpikir dan bertindak baik bagi individu maupun kelompok) yang terus hidup di lingkungan masyarakat hingga sekarang untuk memobilisasi sumber dan optimalisasi potensi dalam penanggulangan Napza. Secara harafiah, stimulan dapat diterjemahkan sebagai suatu rangsangan dan/atau dorongan untuk berpikir dan bertindak baik bagi individu maupun kelompok. Menurut Soetomo (2009) tindakan bersama suatu kelompok atau masyarakat dimulai dari keinginan untuk berubah. Pada mulanya mungkin saja keinginan tersebut berasal dari seseorang yang merupakan bagian dari suatu masyarakat atau bahkan berasal dari pihak luar. Namun demikian, agar dapat menjadi pendorong tindakan bersama, ide atau prakarsa untuk berubah harus ditransformasikan menjadi kebutuhan bersama.

Di era reformasi, kepedulian masyarakat, lembaga usaha dan Pemerintah di DI Yogyakarta untuk menekan angka korban penyalahgunaan dan peredaran gelap narkotika sangat besar. Kondisi ini tercermin dari pokok bahasan di setiap segmen, baik di kalangan legislatif, eksekutif, yudikatif, sampai di tingkat 
masyarakat. Kebijakan dan implementasinya secara komprehensif telah banyak dilakukan. Kondisi ini tercermin dari aksi penyadaran masyarakat (awarenes campaign) tentang bahaya penyalahgunaan napza di Yogyakarta tidak hanya dianggap sebagai suatu tanggung jawab moral, tetapi telah dijadikan sebagai kewajiban bagi seluruh unsur masyarakat (Perda nomor 13/2010). Dalam Peraturan Daerah tersebut, institusi Pemerintah Daerah, Lembaga Pemerintah di Daerah, DPRD, penanggung jawab pemondokan dan asrama, tempattempat usaha, penanggung jawab hotel, penginapan atau tempat hiburan mempunyai kewajibaan untuk melaksanakan: (1) kampanye dan penyebaran informasi yang benar mengenai bahaya penyalahgunaan dan peredaran gelap napza; (2) membuat aturan (pelarangan) peredaran dan penyalahgunaan napza di lingkungannya; dan (3) ikut mengawasi agar tidak terjadi peredaran gelap dan penyalahgunaan napza.

Kepedulian masyarakat dalam P4GN mendapat dukungan dari Sri Sultan Hamengkubuwono X, Gubernur dan Sultan Yogyakarta. Dalam pembukaan pertandingan melukis pada tanggal 22 Juni di Lapas Narkotika Yogyakarta Sri Sultan Hamengkubuwono $X$ mengemukakan "Saya mengimbau kepada lembaga dan komunitas agar Yogyakarta bisa menjadi orang tua bagi anak-anak muda dari luar daerah - supaya para pelajar tidak terlibat dalam penggunaan narkoba" (Prakoso, 2012).

Kampanye penyadaran tentang bahaya penyalahgunaan narkoba juga diselenggarakan pada peringatan Hari Anti Narkoba Internasional Yogyakarta (Rabu, 26/06/2013). Kampanye ini diikuti dan didukung oleh institusi dan organisasi antara lain, TNI AU, TNI AL, TNI AD, komunitas reptile, komunitas anjing, komunitas Vespa, Badan Eksekutif Mahasiswa Se-DIY, ikatan mahasiswa daerah, ikatan waria Yogyakarta dan lain-lain, mencapai lebih dari 87 organisasi dari yang direncanakan GRANAT DIY. (bemkm.student.uny.ac.id, 2013).

Kepedulian ini tercermin dari kampanye anti narkoba yang diselenggarakan keluarga, LSM, Lembaga pendidikan, Komunitas peduli masalah narkoba, bahkan tumbuh suburnya lembaga Rehabilitasi Sosial Berbasis Masyarakat (RBM) yang bertaburan di tingkat desa terutama di wilayah yang dikategorikan sebagai wilayah rawan narkoba dan perkumpulan komunitas peduli korban narkotika. Manifestasi kepedulian masyarakat ini terlihat dari adanya grafiti, poster yang dipasang di tempat strategis yang mudah dibaca masyarakat dan di sekitar gang (jalan) masuk permukiman masyarakat, pembagian stiker pada pengendara, penerapan peraturan pada setiap hotel tentang larangan penggunaan narkotika, di lingkungan sekolah dan kampus, serta penyampaian pesan moral pada event yang dianggap penting oleh masyarakat.

Dalam kerangka pengawasan di tingkat masyarakat, di beberapa desa telah terbentuk satuan tugas (satgas) anti narkoba. Menurut Untoro (Kepala Dinas Transmigrasi dan Sosial Kabupaten Sleman):

Di Sleman sudah terbentuk 18 Satgas anti narkoba di tingkat desa dari 86 desa yang ada.Tiap tahun kami terus berupaya untuk menumbuhkan hingga dalam kurun waktu tertentu Satgas dapat terbentuk di semua desa. Satgas ini merupakan bentuk partisipasi masyarakat dalam pencegahan penyalahgunaan napza. Untuk pengembangan Satgas kami fasilitasi dalam bentuk pertemuan (Rapat 
Koordinasi Satgas) dan kami selalu mengadakan kunjungan.

Kegiatan yang diselenggarakan oleh Satgas di tiap desa cukup banyak. Menurut ketua RBM Gerhana desa Meguwoharjo, Kec. Depok Kabupaten Sleman: Kami telah membentuk Satgas Anti narkoba yang anggotanya terdiri dari perwaklian tiap perdukuhan. Tugasnya adalah meliputi: pemetaan dan memantau kondisi lingkungan terkait dengan napza. Pembentukan Satgas anti Narkoba juga dilakukan oleh pemuda dari kalangan organisasi kemasyarakatan. Sekretaris DPD KNPI Sleman Sandro menjelaskan sebanyak 80 peserta dari Organisasi Kemasyarakatan Pemuda (OKP) dikukuhkan sebagai Satgas Anti Narkoba. Mereka berasal dari 30 perwakilan organisasi pemuda di Sleman. Satgas itu berfungsi untuk mencegah peredaran narkoba di kalangan pemuda. 30 OKP yang tersebar di Sleman beranggotakan beragam usia antara 18 sampai 20 tahun," (Sunartono, 2013).

Kepedulian masyarakat tersebut juga dapat diamati dari semangat masyarakat DI Yogyakarta dalam mengikuti kompetisi “Lomba Kampung Bersih Narkoba" yang diselenggarakan oleh Badan Narkotika Nasional Yogyakarta tahun 2010. Tiga pilar utama dalam penilaian lomba adalah kampung itu mampu mencegah, menyembuhkan, dan membentengi warganya dari narkoba (Gunawan, Sugiyanto, \& Roebyanto, 2013). Sebagai ilustrasi adalah semangat masyarakat pemuda di Dukuh Selo Gedong Desa Argodadi, Kecamatan Sedayu Kabupaten Bantul dalam kompetisi Kampung Bersih Narkoba. Sumbangan masyarakat yang dialokasikan untuk kegiatan tersebut sangat besar. Menurut Kadri, Ketua RMB Bariton:

Jika dikonversikan dengan uang, maka dukungan masyarakat itu kira kira lebih dari 25 juta rupiah tidak sebanding dengan hadiah yang kami terima. Kampung kami juara lomba dan memperoleh hadiah sebesar 15 juta rupiah. Namun ada hal yang membanggakan bagi kami, yaitu ada niatan pemuda untuk menghapus cap merah di kampung, pesan moral "say no to drug" juga kami sampaikan melalui kesenian, budaya dan olahraga dan semua itu mendapat dukungan dari masyarakat terutama kalangan remaja dan pemuda.

Uraian ini mengindikasikan bahwa penyelenggaraan P4GN tidak hanya sebatas pada kelompok tetapi lebih luas lagi adalah keterlibatan masyarakat. Artinya keberhasilan dari aktivitas yang diselenggarakan sudah menjadi milik dan tanggung jawab masyarakat.

Pengejawantahan dari partisipasi masyarakat dalam P4GN ini mendapat apresiasi dan dukungan dari instansi sektoral, BNN dan Kepolisian. Dalam diskusi kelompok terfokus pada hari Kamis tanggal 26 September 2013 di aula Dinas Sosial, lembaga yang hadir dalam diskusi telah mempunyai program yamg ditujukan untuk peningkatan kapasitas masyarakat dalam P4GN, kerjasama dalam penyelenggaraan rehabilitasi sosial korban narkotika di Instansi Penerima Wajib Lapor, dan beberapa program penunjang (pemberdayaan masyarakat) untuk pemulihan ekonomi korban narkotika.

Hal yang menarik dari gerakan sosial yang terjadi di Yogyakarta adalah gerakan aliansi pendukung pencegahan dan rehabilitasi korban narkotika dari komunitas korban narkotik (pecandu dan mantan pecandu). Gerakan yang dilakukan tidak hanya sebatas pada pencegahan penyalahgunaan narkotika tetapi termasuk di dalamnya adalah memperjuangkan diri untuk memperoleh hak pelayanan rehabilitasi dan pengakuan atas hukum sebagai 
warga negara yang baik. (Gunawan, Sugiyanto, \& Roebyanto, 2013). Lembaga komunitas korban Narkotika yang dapat dijumpai dari penelitian ini adalah ARMETh (All Recovering Addict and Metadoners). Komunitas korban narkotika yang tergabung dalam ARMEth tidak hanya bertujuan untuk memperjuangkan kepentingan para anggotanya untuk memperoleh hak (secara ekslusif), tetapi lembaga ini juga merupakan wadah untuk mendidik masyarakat luas dalam perlawanan terhadap penyalahgunaan dan peredaran gelap narkotika. Koordinator ARMETh mengemukakan:

"Tahun 2010 kita (kelompok) dari rehab yang sudah clean (mantan pecandu) ada pemikiran bagaimana bisa membantu teman teman yang yang terkena kasus, apalagi mereka yang tidak pernah ketemu orang. Selama ini pecandu hanya bermasalah dengan hukum, kesehatan dan HAM, kami melakukan pendampingan kepada teman yang tertangkap, selama proses hukumnya berlangsung kita dampingi. Kami ini adalah warga klas 2 yang kurang mendapat tempat di masyarakat, kami berhimpun untuk mendapatkan hak sebagaimana warga masyarakat yang lain. Kami sedang dalam proses melakukan kegiatan positif dan kami membutuhkan kerjasama dan jejaring dengan bapak dan ibu yang hadir di sini. Kami juga siap untuk sharing informasi tentang bahaya penyalahgunaan napza pada adik- adik pelajar agar tidak terjerumus".

Dalam kerangka pencegahan penyalahgunaan narkotika, ARMETh difasilitasi BNNP Yogyakarta. gerakan yang dilakukan antara lain: bekerja sama dengan RBM Putra Mataram dalam kampanye penyadaran terhadap bahaya penyalahgunaan narkotika di sekolah. Pencegahan yang dilakukan tidak hanya ditujukan pada pencegahan primer (kondisi sebelum terjadi) dan pencegahan sekunder (pada saat orang mulai mencoba) tetapi pencegahan yang dilakukan sampai pada pencegahan tersier, yakni pencegahan yang ditujukan pada korban narkoba (baik pecandu maupun mantan pecandu). Kegiatan pencegahan pada prinsipnya merupakan salah satu bentuk layanan rehabilitasi (pemulihan) bagi korban napza. Dalam kerangka pemulihan, korban napza membutuhkan pelayanan yang komprehensif. Di satu sisi, korban napza sedang mengalami penurunan kondisi diri (fisik dan mental). Di sisi lain korban napza harus memperjuangkan diri untuk (1) pemulihan nama baik dari stigma masyarakat dan hilangnya kepercayaan (trust) masyarakat; (2) hak hukum (untuk memperoleh perlindungan); dan (3) pemulihan kondisi ekonomi yang selama ini telah habis digunakan untuk kebutuhan pengobatan. Kegiatan semacam ini juga dilakukan oleh lembaga yang dibentuk masyarakat seperti Lembaga Rehabilitasi Sosial Berbasis Masyarakat (RBM) yang telah ada di setiap desa.

Uraian di atas mengindikasikan bahwa, penyelenggaraan kegiatan P4GN sudah dijadikan sebagai komitmen antara pemerintah dan masyarakat.

Terbentuknya Kelembagaan (baik Lembaga RBM, Satgas anti narkoba desa, Satgas Anti narkoba dari unsur lembaga kemasyarakatan, maupun lembaga yang dibangun komunitas korban) bukan semata mata inisiatif pemerintah, namun merupakan inisiatif bersama (pemerintah dan masyarakat). Kelembagaan anti narkoba yang terbentuk di Yogyakarta yang ada merupakan senbuah kekuatan besar dalam P4GN. Persoalannya adalah bagaimana kelembagaan yang ada tersebut dapat menyatu, bersinergi, dan terkoordinasi dengan baik, sehingga dapat menjadi kekuatan yang utuh. Tentunya untuk dapat memerankan ini diperlukan sebuah model yang mampu 
mengakomodasikan seluruh unsur secara menyeluruh (komprehensif) menjadi lebih kuat.

\section{Eksistensi Partisipasi Masyarakat dalam P4GN.}

Dalam teori sosial, pendekatan yang digunakan untuk menunjuk peran masyarakat adalah pendekatan partisipasi, sehingga peran serta masyarakat dimaknai sebagai bentuk lain dari partisipasi. Menurut Davis (1967:128): participation is defined as mental and emotional involvement of a person in a group situation which encourages him to contribute to group goals and share responsibility in them. Dari pengertian ini terdapat tiga hal yang penting dalam partisipasi yakni:

1) Keterlibatan mental dan emosi seseorang yang lebih dari pada sekedar keterlibatan fisik

2) Partisipasi memotivasi orangorang untuk mendukung situasi kelompoknya, dalam arti mereka menyumbangkan inisiatifnya untuk mencapai sasaran kelompok

3) Mendorong orang untuk ikut serta bertanggung jawab atas aktivitas kelompok.

Secara instrumental Talizidu Ndraha (1990) mengemukakan bahwa bentuk-bentuk partisipasi dapat dikelompokkan dalam 5 bentuk dukungan, yakni: 1) partisipasi buah pikiran, 2) partisipasi keterampilan. 3) partisipasi tenaga, 4) partisipasi harta benda, 5) partisipasi uang.

Konsep Davis pada dasarnya dapat diimplementasi pada satu mata rantai kegiatan, mulai dari perencanaan, pelaksanaan, pemanfaatan dari hasil partisipasi tersebut. Dalam kerangka optimalisasi partisipasi Ife, J. dan Tesoriero, F. (2006:312-313) mengemukakan bahwa mendorong dan mendukung partisipasi adalah suatu proses yang membutuhkan keterampilan, dan melibatkan pemantauan terus menerus tentang dampaknya terhadap rakyat mengenai partisipasi mereka ke dalam kegiatan pengembangan masyarakat. Partisipasi harus menghasilkan keluaran positif, baik dari segi membangun kepercayaan pribadi dan dalam segi kontrol terhadap lingkungan seseorang dan kemampuan untuk mempengaruhi keputusan yang akan memberi dampak pada kehidupan orang. Uraian ini mengisyaratkan bahwa partisipasi masyarakat dipandang sebagai suatu kekuatan besar dalam penyelenggaraan berbagai kegiatan. Oleh karena itu partisipasi dapat dimanipulir sebagai suatu cara dan atau strategi (termasuk dalam pencapaian P4GN). Menurut Soelaiman dalam Iskandar (1993:74) secara konseptual partisipasi sosial merupakan alat dan tujuan pembangunan masyarakat. Sebagai alat dan sarana pembangunan, partisipasi berfungsi sebagai penggerak dan pengarah proses perubahan sosial; demokratisasi kehidupan sosial ekonomi dan politik yang berazaskan pemerataan keadilan sosial; pemerataan pelaksanaan serta hasil pembangunan; pemupukkan harga diri dan kepercayaan kepada kemampuan masyarakat itu sendiri serta pemupukan rasa kesadaran dan solidaritas sosial. Sebagai tujuan, partisipasi sosial merupakan perwujudan kehidupan masyarakat yang sejahtera dan berkeadilan.

Aspek yang menarik dari fenomena kepedulian dan partisipasi masyarakat Yogyakarta adalah adanya ketentuan hukum (Peraturan Daerah Nomor 13 Tahun 2010 tentang Pencegahan dan Penanggulangan terhadap Penyalahgunaan dan Peredaran Gelap Narkotika). Dalam 
pasal 12 dinyatakan bahwa masyarakat berkewajiban untuk:

1) Ikut melaksanakan kampanye dan penyebaran informasi yang benar mengenai bahaya penyalahgunaan dan peredaran gelap Narkotika, Psikotropika, dan Zat Adiktif;

2) Melaksanakan program hidup bersih sehat di wilayah masingmasing;

3) Menggerakkan kegiatan sosial masyarakat melawan peredaran dan penyalahgunaan Narkotika, Psikotropika, dan Zat Adiktif di wilayah masing-masing;

4) Membentuk satuan tugas di tingkat Rukun Tetangga;

5) Meningkatkan pengawasan terhadap kegiatan-kegiatan masyarakat yang berpotensi terjadi penyalahgunaan dan peredaran gelap Narkotika, Psikotropika, dan Zat Adiktif.

Jika dicermati, klausul dalam pasal 12 dapat diinterpretasikan sebagai alat untuk memobilisasi sumber daya manusia dalam pencapaian tujuan. Disadari atau tidak, peraturan tersebut telah mengikat seluruh masyarakat Yogyakarta. Artinya partisipasi masyarakat telah dijadikan sebagai kewajiban masyarakat dalam penyelenggaraan P4GN.

Telaahan terhadap uraian di atas dapat dikemukakan bahwa kepedulian masyarakat merupakan salah satu manifestasi dari partisipasi masyarakat dalam P4GN, bahkan kepedulian masyarakat tersebut dapat dikategorikan sebagai sebuah gerakan sosial. Meskipun dalam naskah ini tidak bertujuan untuk menguji pandangan Davis (1967), tetapi uraian di atas telah dapat menjelaskan indikator dari konsep yang dibangun Davis. Jika ditelusuri lebih jauh (ditinjau dari manifestasi partisipasi sebagai keterlibatan mental dan emosi serta fisik masyarakat dalam pencegahan penyalahgunaan dan peredaran narkotika, serta dukungan untuk pencapaian tujuan dan tanggung jawab atas keterlibatannya), maka konsep yang dibangun Davis telah dikonstruk di lingkungan masyarakat Jawa sejak ratusan tahun yang lalu, yakni sejak Mangkunegara I menggelar ajaran yang dikenal dengan "Tri Dharma Amerta". Muatan dari ajaran ini adalah: Rumangsa Melu Handarbeni, Rumangsa Melu Hangrungkebi, Mulat Sariro Hangroso Wani. Kanjeng Gusti Mangkunegara I (RM Pangeran Samber Nyawa) itu berpesan kepada pengikutpengikutnya bahwa dalam membela negara itu hendaknya semua merasa: Rumangsa melu handarbeni, "Ini negaramu. Ini bukan hanya negara Rajamu saja, melainkan negaramu juga, negara rakyat Mangkunegara." Kalau sudah merasa turut handarbeni, merasakan itu juga miliknya, bukan hanya milik pimpinannya melainkan milik seluruh rakyat yang turut berjuang, maka kemudian melaksanakan kewajiban yang kedua: wajib melu hangrungkebi, merasa ikut membela. Kemudian, melaksanakan yang ketiga, mawas diri: Mulat sarira hangrasa wani. Coba supaya kita selalu mawas diri, apakah dharma kesatu dan kedua itu ada pada diri kita masingmasing? (Soeharto, 2014).

Secara prinsip ajaran Tri Dharma Amerta ini dapat diimplementasikan dalam berbagai kegiatan untuk tujuan kemaslahatan manusia, termasuk dalam kegiatan P4GN, baik dalam skope lokal (desa), nasional, maupun internasional. Tentunya ajaran Tri Dharma Amerta ini dapat dijadikan sebagai salah satu review tentang konsep partisipasi. Lima bentuk dukungan (partisipasi) yang diajukan oleh Ndraha (1990) memang telah banyak membantu 
untuk melihat seberapa besar kontribusi dari masyarakat. Namun tinjauan partisipasi dari Ndraha terebut perlu dilengkapi dari aspek psikologi (seperti keterlibatan mental dan emosional yang diajukan oleh Davis, dan ajaran Tri Dharma Amerta dari Mangkunegoro). Keterlibatan mental emosional (Davis) Melu Handarbeni merupakan salah satu penekanan sense of belonging dari partisipan.

Peran masyarakat Yogyakarta dalam P4GN dapat diamati dari kontribusi dalam lima bentuk sumbangan yang dikemukakan oleh Ndraha. Dukungan yang diberikan mulai dukungan yang bersifat insidental pada event tertentu (dukungan dari simpatisan) sampai dengan dukungan yang bersifat berkelanjutan (dukungan dari aktivis, penyandang dana). Dukungan berkelanjutan umumnya dilakukan oleh masyarakat yang telah membentuk suatu lembaga atau organisasi di tingkat lokal. Kondisi ini tercermin dari maraknya pembentukan lembaga RBM di tingkat desa. Menurut Soetomo (2006: 388), dalam kehidupan masyarakat tingkat komunitas akan lebih mudah diorganisasikan berbagai bentuk tindakan bersama, termasuk tindakan bersama untuk memenuhi kebutuhan warga mayarakat secara individual apalagi kebutuhan kolektif. Hal itu disebabkan karena pada tingkat komunitas masih lebih kental dirasakan adanya kesadaran kolektif, solidaritas sosial dan kepentingan bersama. Dengan demikian, apabila masyarakat lokal memiliki komitmen tentang suatu gagasan sebagai bentuk prakarsa dan kreativitas dari dalam, mereka akan berusaha untuk memobilisasi sumber daya yang ada melalui tindakan bersama guna merealisasikan gagasan tersebut.

Fenomena kepedulian dan partisipasi masyarakat Yogyakarta dalam P4GN merupakan manifestasi dari suatu gerakan sosial. Gerakan tersebut utamanya adalah untuk menarik perhatian dan dukungan masyarakat luas dalam melawan gempuran peredaran gelap narkotika dan penyalahguna narkotika (anonim). Sebagai suatu gerakan, Sztompka (2005) mengemukakan bahwa komponen (syarat minimal) gerakan sosial harus terdiri dari komponen: (1) kolektivitas orang yang bertindak bersama; (2) tujuan bersama tindakannya adalah perubahan tertentu dalam masyarakat yang ditetapkan partisipan menurut cara yang sama; (3) kolektivitasnya relatif tersebar namun lebih rendah derajatnya daripada organisasi formal; (4) tindakannya mempunyai spontanitas relatif tinggi namun tidak melembaga dan bentuknya tidak konvensional. Dari pandangan Sztomka ini, aksi masyarakat sudah memenuhi syarat sebagai suatu gerakan. Dalam gerakan akan terlihat beberapa lapisan partisipan mulai dari aktivitas inti, pengikut, simpatisan, hingga penunggang bebas, yang bersimpati kepada gerakan dari jauh dengan harapan kemenangannya akan memberikan keuntungan pula kepada mereka. Komposisi seperti kulit bawang ini akan terbukti bila gerakan mengalami kesukaran, ditindas atau dikalahkan, lapisan terluar akan ngacir terlebih dahulu meninggalkan persoalan, sedangkan aktivis inti akan bertahan, adakalanya menghidupkan kembali gerakan di kemudian hari.

Gerakan masyarakat Yogyakarta dalam P4GN adalah gerakan yang bersifat non-kelas dan tidak menghiraukan latar belakang agama dan etnis. Artinya subjek gerakan ini tidak hanya berasal dari kelas khusus tertentu tetapi mencakup berbagai kelas (internal) maupun unsur masyarakat yang berada di luar areal (eksternal) seperti mahasiswa, kaum urban, kaum menengah, komunitas tertentu yang ada 
di dalam masyarakat. Dalam pengertian ini adalah menyatunya antara pemerintah dan masyarakat dari berbagai aliran (agama dan etika). Gerakan diselenggarakan baik dalam bentuk aksi damai maupun himbauan. Pada prinsipnya gerakan sosial dilakukan untuk (1) menarik perhatian dan memperoleh dukungan dari masyarakat luas dalam menekan angka penyalahgunaan napza dan pencegahannya; (2) perubahan prilaku individu maupun kolektif. Tujuan gerakan tidak hanya untuk perbaikan satu kelompok atau golongan tertentu tetapi bertujuan untuk perbaikan masa yang akan datang demi kemaslahatan seluruh umat di berbagai lapisan.

Gerakan yang terjadi tidak bersifat satu arah untuk perubahan yang dikehendaki dari atas ataupun hanya gerakan arus bawah, tetapi gerakan ini merupakan kombinasi dari dua arus (arus atas dan arus bawah), bahkan gerakan ini dapat dimaknai sebagai gerakan semesta dan difasilitasi beberapa lembaga yang mempunyai komitmen dalam P4GN. Dalam gerakan ini telah terbentuk jaringan sosial antar instansi sektoral, jaringan antar instansi sektoral dengan masyarakat, dan jaringan antar masyarakat. Sebagai ilustrasi, bentuk jaringan yang terbangun antara lain: Badan Narkotika Yogyakarta telah memfasilitasi terbentuknya ARMETh dan didukung dengan Program Rumah Kreatif, Kementerian Sosial memfasilitasi terbentuknya Lembaga RBM di tingkat provinsi, Dinas Sosial Kabupaten memfasilitasi pembentukan lembaga RBM lokal (desa), instansi pendidikan membentuk kader anti narkoba di sekolah, dan penunjukkan Instansi Penerima Wajib Lapor (IPWL) dalam penyelenggaraan rehabilitasi sosial bagi korban narkotika. Menurut Field (2010) orang berhubungan melalui serangkaian jaringan dan mereka cenderung memiliki kesamaan nilai dengan anggota lain dalam jaringan tersebut; sejauh jejaring tersebut menjadi sumber daya, dia dapat dipandang sebagai modal. Selain bisa memberikan manfaat langsung, modal sosial ini seringkali bisa dimanfaatkan dalam latar yang lain. Jaringan sosial merupakan aset yang sangat bernilai. Jaringan memberikan dasar bagi kohesi sosial karena mendorong orang-orang bekerja sama satu sama lain - dan tidak hanya sekedar dengan orang yang mereka kenal secara langsung - untuk memperoleh manfaat timbal balik. Modal sosial bisa disebut dengan modal selama hal ini melahirkan sumber daya yang dapat dimanfaatkan untuk memberdayakan aktor - individu dan kelompok - untuk mencapai tujuan mereka secara lebih efektif dari pada mereka melakukan tanpanya.

Gerakan sosial tersebut semakin gencar ketika diketahui bahwa permasalahan penyalahgunaan narkotika mempunyai korelasi dengan berkembangnya penyakit HIV/AIDS. Hal ini dapat disebabkan karena program-program penanggulangan AIDS lebih mudah memperoleh pendanaan dari berbagai sumber, juga lebih jelas sasaran dan indikatornya, yaitu mengurangi penularan HIV/ AIDS di masyarakat (Iswandari, S., Siahaan S., Rahajeng, E., Indrawan. L., 2011).

Dalam perkembangan teori gerakan sosial, aksi masyarakat Yogyakarta di atas mengindikasikan sebagai suatu bentuk gerakan sosial baru. Menurut David Aberle dikategorikan sebagai Alternative Movement yang bertujuan untuk merubah sebagian perilaku perorangan. Dalam kategori ini dapat kita masukan berbagai kampanye untuk merubah perilaku tertentu, seperti misalnya kampanye agar orang tidak minumminuman keras. Dengan semakin menyebarnya penyakit AIDS kini pun 
banyak dilancarkan kampanye agar dalam melakukan perbuatan sex hendaknya dilakukan secara bertanggung jawab (Abiechuenk, 2010).

Gerakan anti narkotika masyarakat DIY pada dasarnya bukan pada bentuk perlawanan masyarakat melawan elite maupun pemerintah, sebagaimana gerakan sosial lama yang selalu mengusung suatu ideologi dan perjuangan kaum proletar, masyarakat marjinal ataupun masyarakat yang subordinan. Meskipun gerakan tersebut dilakukan dalam bentuk aksi damai, dan penyadaran berperilaku untuk tidak menyalahgunakan narkotika, namun persoalannya tetap saja merupakan satu perjuangan untuk melawan musuh yang tidak jelas (anonim) seperti pengedar gelap dan seluruh mata rantainya.

Dalam pencapaian tujuan P4GN, ekspresi gerakan masyarakat Yogyakarta ini tidak termasuk dalam kategori melanggar ketentuan peraturan perundangan, sistem atau mempertanyakan legitimasi dari otoritas negara, bahkan gerakan tersebut merupakan salah satu kewajiban bagi masyarakat.

Dari segi yuridis, masyarakat memang diberikan peluang untuk mengekspresikan gerakan sosial (awareness campaign) bahkan didukung Pemerintah. Legitimasi suatu gerakan ini juga dapat dicermati dari Peraturan Presiden No 23 Tahun 2010 tentang Pembentukan Badan Nasional Narkotika (BNN), Pasal 3 huruf g, bahwa tugas dan fungsi BNN adalah pengoordinasian instansi pemerintah terkait dan komponen masyarakat dalam rangka penyusunan dan perumusan serta pelaksanaan kebijakan nasional di bidang P4GN. Interpretasinya adalah masyarakat merupakan salah satu unsur dalam penyelengara $\mathrm{P} 4 \mathrm{GN}$, sehingga program dan akitivitasnya dijadikan sebagai bagian dari program nasional. Bahkan dalam Perda DI Yogyakarta Nomor 13/2010 mewajibkan masyarakat untuk ikut berperan dalam penyelenggaraan P4GN. Sedangkan dari segi hukum agama dan etika (wulang reh) telah mengecam penggunaan narkotika sebagai salah satu bahan yang dikonsumsi, bahkan dari segi agama narkotika merupakan salah satu jenis barang yang diharamkan untuk dikonsumsi.

Ketentuan hukum baik hukum formal maupun hukum agama dan etika merupakan sumber kekuatan (energi sosial) bagi masyarakat dalam penyelenggaraan gerakan P4GN untuk menjaga eksistensi hukum agama dan sosial terkait dengan P4GN. Menurut Soetomo (2012) sumber energi sosial dalam masyarakat berupa nilai kemandirian, solidaritas, kesadaran kolektif, tanggung jawab sosial yang mendorong terwujudnya tindakan bersama. Tidak dapat diingkari bahwa setiap orang sebagai individu mempunyai aspirasi, kepentingan yang dapat berbeda dengan orang lain sesama warga masyarakat. Kunci terpeliharanya energi sosial adalah adanya komitmen bersama dan kesadaran akan tujuan bersama. Asumsinya, semakin kuat besar energi sosial yang dapat dikelola dengan baik akan semakin besar pula hasil yang akan dicapai dari kegiatan tersebut.

Aspek yang menarik untuk dijadikan sebagai sebuah telaahan adalah prestasi masyarakat Yogyakarta dalam penurunan angka peringkat penyalahgunaan narkotika dari urutan ke dua pada tahun 2010 menjadi urutan kelima pada tahun 2013. Gerakan masyarakat sebagai suatu kekuatan besar dapat berfungsi sebagai (1) penyadaran masyarakat terhadap bahaya narkotika dan (2) sebagai tindakan untuk mempersempit dan 
menekan peredaran narkotika. Persoalannya adalah menurunnya angka korban narkotika ini sebagai akibat dari meningkatnya kesadaran masyarakat atau karena ruang gerak peredaran gelap yang semakin sempit. Atau keduanya mempunyai pengaruh yang signifikan dalam penurunan angka korban narkotika?

Dalam arti yang lebih luas, Gerakan Sosial Masyarakat Yogyakarta dalam P4GN dapat dipandang sebagai sebuah refleksi dari gerakan anti narkotika global. Kondisi ini tercermin dari Deklarasi Yogyakarta Zero Narkoba 2015 dari seluruh elemen masyarakat Yogyakarta dan tergabung dalam Gerakan Anti Narkoba Nasional. Deklarasi ini merupakan target pijakan dalam menggerakkan seluruh komponen masyarakat secara aktif untuk meningkatkan kewaspadaan akan bahaya narkoba bagi kelangsungan hidup. Secara umum, inti dari kerjasama penanggulangan, pemberantasan penyalahgunaan dan peredaran gelap narkoba (P4GN) di tingkat regional ASEAN diarahkan pada upaya realisasi komitmen A Drug Free ASEAN 2015 (Kawasan Bebas Narkoba ASEAN 2015), yang dipertegas dalam Rencana Aksi Komunitas Sosial-Budaya. Upaya di tingkat regional tersebut diselaraskan dengan langkah-langkah di tingkat nasional yang menetapkan pencapaian Kawasan Bebas Narkoba Indonesia 2015 (FORKON, 2011).

Beberapa hal penting yang dapat dijadikan sebagai dasar bahwa gerakan masyarakat Yogyakarta merupakan gerakan Global antara lain:

1) Dari segi hukum, United Nations Convention Against Illicit Traffic in Narcotic Drugs and Psychotropic Substances, 1988 telah diratifikasi dengan Undang-Undang Nomor 7 Tahun 1997 tentang Pengesahan United Nations
Convention Against Illicit Traffic in Narcotic Drugs and Psychotropic Substances, 1988.

Ditetapkannya tanggal 26 Juni sebagai sebagai hari Anti Madat Sedunia oleh International Day Against Drugs.

2) Dalam kerangka optimalisasi hasil P4GN, Pemerintah dan Dewan Perwakilan Rakyat Republik Indonesia (DPR RI) mengesahkan Undang-Undang Nomor 5 Tahun 1997 tentang Psikotropika dan UndangUndang Nomor 22 Tahun 1997 tentang Narkotika dan membentuk Badan Koordinasi Narkotika Nasional (Keputusan Presiden Nomor 116 Tahun 1999). Perkembangan berikutnya adalah membentuk Badan Narkotika Nasional (Keputusan Presiden Nomor 17 Tahun 2002). Optimalisasi kinerja BNN tersebut telah didukung dengan Peraturan Presiden Nomor 83 Tahun 2007 tentang Badan Narkotika Nasional, Badan Narkotika Propinsi (BNP) dan Badan Narkotika Kabupaten/Kota (BNK).

3) Instruksi Presiden No. 12/2011 tentang Pelaksanaan Kebijakan dan Strategi Nasional Pencegahan dan Pemberantasan Penyalahgunaan Peredaran Gelap Narkoba (P4GN) tahun 2011-2015 yang ditujukan kepada Para Menteri Kabinet Indonesia Bersatu II, Sekretaris Kabinet, Kepala Kepolisian Negara RI, Jaksa Agung, Panglima Tentara Nasional Indonesia, Kepala Badan Koordinasi Penanaman Modal, Para Kepala Lembaga Pemerintah non Kementerian, Para Gubernur, dan Para Bupati dan Walikota untuk mengambil 
langkah-langkah yang diperlukan sesuai tugas, fungsi dan kewenangan masing-masing dalam rangka pelaksanaan Kebijakan Strategi Nasional (Jakstranas) P4GN 2011-2015 yang meliputi bidang: (a) Pencegahan; (b) Pemberdayaan masyarakat; (c) Rehabilitasi; dan (d) Pemberantasan. Sedangkan di tingkat Daerah telah dikeluarkan Peraturan Daerah Nomor 13 Tahun 2010 tentang Pencegahan dan Penanggulangan terhadap Penyalahgunaan dan Peredaran Gelap Narkotika.

4) Konferensi tingkat dunia dalam bidang penanggulangan kejahatan Narkoba atau dikenal dengan istilah International Drugs Enforcement Conference (IDEC), di Nusa Dua, Bali, tanggal 12 hingga 14 Juni 2012. Pelaksanaan IDEC XXIX dengan tema "Enhancing The Spirit of International Partnership to Achieve the Greatest Success on Fighting Drug Crime" Kegiatan tersebut diikuti oleh 55 negara anggota IDEC (Members) dan 24 negara anggota pengawas (Observers). (Indomediatv, 2012)

5) Di kawasan regional, fenomena besarnya permasalahan narkotika telah dijadikan sebagai salah satu isu krusial yang membutuhkan penanganan serius. Keseriusan negara-negara ASEAN dalam penanganan permasalahan narkoba, antara lain tercermin dari pertemuan ASEAN Senior Officials on Drugs Matters (ASOD), Senior Officials Meeting on Transnational Crimes (SOMTC), ASEAN and China Cooperative Operations in Response to Dangerous Drugs (ACCORD). Dalam pertemuan ASEAN
Summit 2012 di Kamboja tanggal 3-4 April 2012, para Kepala Negara anggota menyetujui untuk bersama-sama memerangi peredaran narkoba di antara negara-negara anggota. Persetujuan tersebut terlampir lewat sebuah deklarasi yang diberi nama "Declaration on Drug-Free ASEAN 2015". Dalam kerangka realisasi Deklarasi ASEAN tersebut, telah digelar Sidang Executive Committee (Excom) of Asean InterParliamentary Assembly (AIPA) dan The Ninth Meeting of AIPA Fact Finding Committee (AIFOM) to Combat The Drug Menace, 8 - 12 Juli 2012 di Hyat Regency Hotel Yogyakarta dalam pertemuan yang diselenggarakan bertepatan dengan Hari Anti Narkotika Dunia. Hasil pertemuan ini adalah Kesepakatan dua buah Draft Resolusi, yaitu Role of Parliaments in Drug Demand and Supply Reduction and the Plan of Action to Combat the Drug Menace Consistent with ASEAN Vision dan Establishment of Technical Working Group of AIFOCOM. Draft Resolusi AIFOCOM telah disepakati untuk diajukan dan disahkan pada Sidang Umum AIPA ke-33 (DPR, 2012).

6) Dalam Sidang Umum AIPA ke33 tanggal 16-22 September di Lombok, AIPA menyepakati keputusan Sidang AIFOCOM Juli, 2012 di Yogyakarta mengenai Rencana Aksi (Plan of Action) untuk Memerangi Kejahatan Narkoba dan juga pembentukan Technical Working Group untuk merumuskan langkah-langkah teknis bagi parlemen dalam memerangi Narkoba (Kemlu, 2012). 


\section{Kontribusi Patisipasi Masyarakat Yogyakarta dalam P4GN}

Penyalahgunaan dan peredaran gelap narkotika merupakan permasalahan yang kompleks. Dampak buruk yang ditimbulkan tidak hanya sebatas pada permasalahan sosial bagi individu, keluarga dan lingkungannya, tetapi telah meluas pada sendi sendi sosial, politik, ekonomi dan keamanan bangsa. Dari kerangka berpikir ini, Gerakan Sosial Masyarakat Yogyakarta, tidak hanya sekedar untuk menarik perhatian masyarakat dan menekan angka korban narkotika di Yogyakarta, namun gerakan masyarakat dalam P4GN telah berimplikasi pada masyarakat luas.

Penyelenggaraan aksi P4GN di Yogyakarta menunjukkan bahwa penyalahgunan dan peredaran gelap narkotika telah menjadi masalah dan tanggung-jawab bersama antara pemerintah dan masyarakat. Partisipasi masyarakat Yogyakarta merupakan arus dari bawah (bottom up) yang bersinergi dengan program pemerintah (top down). Kondisi ini tentunya akan berimplikasi luas, baik bagi masyarakat Yogyakarta sendiri, negara, dan kepentingan internasional, maupun dalam pengembangan model-model penanganan masalah krusial.

Khusus bagi masyarakat Yogyakarta, setidaknya ada beberapa hal yang dapat dipetik, yakni (1) Pemerintah telah memberikan kebebasan, bahkan mendukung masyarakat untuk berekspresi dalam penyelenggaraan aksi P4GN; (2) aksi P4GN akan berkontribusi pada peningkatan pengetahuan dan kesadaran masyarakat terhadap bahaya narkotika; (3) pengetahuan dan kesadaran ini akan membangun motivasi masyarakat untuk memberikan dukungan dalam setiap aksi yang menyangkut kemaslahatan bagi diri, keluarga, dan masyarakat luas; (4) terbentuknya kelembagaan anti narkotika (baik di lingkungan sekolah/kampus maupun di lingkungan masyarakat) yang berfungsi sebagai kontrol sosial. Dalam strategi pengembangan partisipasi masyarakat, kondisi ini telah melewati suatu persyaratan untuk berpartisipasi yang dikemukakan Lee dalam Iskandar (1993). Untuk menumbuhkan partisipasi masyarakat maka harus diciptakan prakondisi yang meliputi (1) otonomi dan kebebasan untuk berpartisipasi (2) kemampuan untuk berpartisipasi dan (3) keinginan untuk berpartisipasi. Terciptanya kondisi seperti ini, akan berimplikasi pada menurunnya angka kejahatan, meningkatnya keamanan lingkungan dan ketenangan bagi pelajar/mahasiswa dan warga masyarakat (aspek psikologik).

Bagi negara gerakan masyarakat dalam P4GN ini juga telah memberikan kontribusi besar pada penurunan permasalahan sosial lain. Jika diprediksi bahwa aksi sosial yang diselenggarakan oleh pemerintah dan masyarakat mampu menekan angka korban penyalahgunaan dan peredaran gelap narkotika sebesar 30 persen, maka partisipasi masyarakat Yogyakarta ini akan berimplikasi pada menurunnya permasalahan sosial ikutan (misalnya: kriminil, seks bebas, kesehatan, kenakalan remaja, ketegangan dan keserahan masyarakat).

Dari segi perekonomian negara, penurunan angka korban ini dapat berimplikasi pada berkurangnya pengeluaran anggaran pemerintah untuk menangani permasalahan narkotik dan dampaknya. Anggaran Pendapatan Belanja Negara (APBN) maupun Anggaran Pendapatan Belanja Daerah (APBD), yang dialokasikan untuk rehabilitasi sosial korban Narkotika dan dampaknya baik melalui BNN dan BNNP maupun instansi 
sektoral dapat dialokasikan untuk program lain yang lebih mendesak bagi kepentingan bangsa.

Dari segi politik, aksi masyarakat Yogyakarta merupakan salah satu bentuk pengejawantahan dari pertanggung-jawaban Pemerintah Republik Indonesia (sebagai salah satu negara peserta ASEAN dan Internasional) dalam P4GN. Dalam konteks ini peran negara tidak hanya sebatas pada percaturan politik dunia dan persetujuan terhadap kesepakatan global (Undang-Undang Nomor 7 Tahun 1997 tentang Pengesahan United Nations Convention Against Illicit Traffic in Narcotic Drugs and Psychotropic Substances, 1988). Gerakan masyarakat Yogyakarta dalam P4GN tersebut dapat dijadikan sebagai salah satu bukti keseriusan bangsa terhadap kesepakatan dunia.

\section{Kesimpulan}

Efektivitas

partisipasi masyarakat pada dasarnya merupakan sebuah kesepakatan atas ide/gagasan masyarakat yang dimanifestasikan dalam bentuk program, pelaksanaan, dan pemanfaatan, serta pemeliharaan hasil yang dicapai. Konsistensi partisipasi ini tentunya dapat dimaknai sebagai suatu kekuatan besar dalam penyelenggaraan setiap aktivitas pengembangan masyarakat. Dalam teori sosial, partisipasi masyarakat telah berfungsi sebagai energi sosial dan merupakan segenap jaringan yang terbentuk antar individu dan kelompok yang berfungsi sebagai modal sosial.

Dinamika partisipasi masyarakat telah berkembang dan dapat dimaknai sebagai alat atau cara (dimanipulasi) untuk mencapai suatu tujuan bersama yang sering disebut sebagai mobilisasi masyarakat. Nilai dari berbagai agama, etika, serta Peraturan Perundangan merupakan determinan penting dan telah mengikat perilaku masyarakat
Yogyakarta untuk mencapai keberhasilan penyelenggaraan P4GN. Artinya, partisipasi tidak hanya sebatas pada kerelaan tetapi sudah dijadikan sebagai suatu kewajiban bagi masyarakat untuk berperan dalam penyelenggaraan P4GN, yakni mulai peringatan Hari Anti Narkotika Indonesia, kampanye penyadaran sosial di lingkungannya, sampai pada strategi yang diterapkan seperti gerakan sosial.

Di Indonesia, manifestasi dari gerakan sosial dalam P4GN ini tentunya tidak hanya dilakukan oleh masyarakat Yogyakarta, tetapi umumnya diselenggarakan di kota yang notabene mempunyai angka prevalensi penyalahgunaan narkotika yang tinggi. Dalam perspektif hubungan internasional, gerakan sosial ini menunjukkan konsistensi dan pertanggungjawaban Negara Republik Indonesia atas kesepakatan ASEAN, dan bangsa- bangsa di dunia dalam P4GN. Meskipun perlawanan masyarakat terhadap penyalahgunaan dan peredaran gelap narkotika tidak dilakukan dengan kontak senjata seperti di Colombia, namun jika partisipasi masyarakat ini diprediksi mampu menekan 30 persen dari jumlah korban narkotika dan mempersempit peredaran gelap narkotika, maka tugas negara dalam mencapai Declaration on DrugFree ASEAN 2015 semakin ringan.

\section{Rekomendasi}

Seiring dengan perkembangan ilmu dan teknologi telah ditemukan berbagai jenis, bentuk, dan kemasan narkotika, serta peruntukan penggunaannya, tetapi strategi yang ditempuh oleh pedagang ilegal pun juga semakin baik dan semakin rapi. Oleh karena itu, kampanye penyadaran masyarakat dan peningkatan kewaspadaan masyarakat luas perlu dilakukan secara terus menerus. Optimalisasi partisipasi masyarakat, 
baik dalam peningkatan kesadaran sosial, kontrol sosial dalam pengawalan kebijakan politik, kesepakatan baik lokal, regional maupun internasional perlu didukung dengan penelitian eksplorasi untuk menemukan model pengembangan kapasitas masyarakat dalam penyelenggaraan P4GN.

Pemuda dan mahasiswa di satu wilayah adalah orang yang paling dekat dan selalu berhubungan dengan masyarakat, bahkan diyakini bahwa mereka adalah pelopor dari setiap gerakan untuk perubahan dan pembaharuan. Analoginya, pemuda dan mahasiswa adalah aktor penting dalam penyelenggaraan P4GN. Terkait dengan Rencana Aksi (Plan of Action) untuk Memerangi Kejahatan Narkoba dan juga pembentukan Technical Working Group untuk merumuskan langkah-langkah teknis bagi parlemen dalam memerangi narkoba yang telah disepakati sebagai agenda kerja komunitas ASEAN, maka kesepakatan Komunitas ASEAN ini tentunya memberikan peluang besar bagi pemuda dan mahasiswa di negara negara ASEAN untuk saling bertukar informasi tentang penyelenggaraan P4GN. Strategi yang mungkin dapat diselenggarakan adalah studi banding dalam bentuk: (1) Penugasan pemuda dan mahasiswa Indonesia untuk studi banding ke negara Komunitas ASEAN atau sebaliknya mengundang Pemuda dan Mahasiswa Komunitas ASEAN ke Indonesia; (2) Workshop antar Pemuda dan Mahasiswa dari negara komunitas ASEAN. Hasil dari studi banding maupun workshop ini tentunya akan besar manfaatnya baik bagi pemerintah, lembaga usaha maupun masyarakat dalam P4GN. Dalam penyelenggaaan kegiatan ini, idealnya difasilitasi oleh pemerintah (baik melalui BNN maupun instansi sektoral).

\section{Daftar Rujukan}

Davis, K. 1967. Human Relation at Work, The Dinamics of Organizational Behavior. Mc Grow Hill Book Company.

Field, J. 2010. Modal Sosial. Kasihan Bantul: Kreasi Wacana.

Gunawan, Sugiyanto, \& Roebyanto. 2013. Eksistensi Rehabilitasi Sosial Berbasis Masyarakat Bagi Korban Penyalahgunaan NAPZA. Jakarta: P3KS Press.

Ibrahim, J. 2013. Opium dan Revolusi: Perdagangan dan Penggunaan Candu di Surakarta Masa Revolusi (1945-1950). Yogyakarta: Pustaka Pelajar.

Ife, J., \& Tesoriero. F. 2008. Community Development: Alternatif Pengembangan Masyarakat di Era Globalisasi. Yogyakarta: Pustaka Pelajar. (edisi 3). Judul Asli: Community Development: Community-Base Alternatives in the Age of Globalization, Pearson Education Australia, Unit 4, level 3, 14 Aquatic Drive Frends Forest NSW, 2006 (edidi 3).

Isfandari, S. Selma Siahaan,S. Rahadjeng, E. \& Indrawati,L. (2011). Analisis Implikasi UU 35/2009 dan UU 36/2009 dalam Pengembangan Strategi Kebijakan Pencegahan dan Terapi Penyalahgunaan Narkotika, Psikotropika dan Zat Adiktif (NAPZA) di Indonesia. Buletin Penelitian Sistem Kesehatan, 24 - 29.

Iskandar, J. 1993. Strategi Dasar Membangun Kekuatan Masyarakat. Bandung: Koperasi Mahasiswa STKS. 
Ndraha, T. 1993. Pembangunan Masyarakat, Mempersiapkan Masyarakat Tinggal Landas. Jakarta: Rineka Cipta.

Simanungkalit, P. 2011. Globalisasi Peredaran Narkoba dan Penanggulangannya. Jakarta: Yayasan Wajar Hidup

Soetomo. 2012. Keswadayaan Masyarakat, Manifestasi Kapasitas Masyarakat Untuk Berkembang Secara Mandiri. Yogyakarta: Pustaka Pelajar.

Soetomo. 2009. Pembangunan Masyarakat, Merangkai Sebuah Kerangka. Yogyakarta: Pustaka Pelajar.

Soetomo. 2006. Strategi -Strategi Pembangunan Masyarakat. Yogyakarta: Pustaka Pelajar.

Szompka, P. 2007. Sosiologi Perubahan Sosial. Jakarta: Pernada Media Grup.

\section{Peraturan Perundangan}

Undang Undang Nomor 35 Tahun 2009 tentang Narkotika.

Undang-Undang Nomor 22 Tahun 1997 tentang Narkotika.

Undang-Undang Nomor 5 Tahun 1997 tentang Psikotropika.

Peraturan Presiden Nomor 23 Tahun 2010 tentang Pembentukan Badan Nasional Narkotika (BNN).

Instruksi Presiden Nomor 12 Tahun 2011 tentang Pelaksanaan Kebijakan dan Strategi Nasional Pencegahan dan Pemberantasan Penyalahgunaan Peredaran Gelap Narkoba (P4GN) tahun 2011-2015.

Peraturan Pemerintah Provinsi Daerah Istimewa Yogyakarta Nomor 13 Tahun 2010 tentang Pencegahan dan Penanggulangan terhadap Penyalahgunaan dan Peredaran Gelap Narkotika.

\section{Internet}

Abiechuenk. (2010, Desember 14). Gerakan Sosial di Indonesia: (Pengertian dan Konsep Gerakan Sosial). Dipetik Februari 22, 2014, dari abiechuenk's.blog: http://abiechuenk.wordpress.com/2010/12/14/gerakan-sosial/\#more-38

bemkm.student.uny.qc.id. (2013, Juli 11). Kampanye Simpatik Hari Anti Narkoba Internasional (HANI). Dipetik Maret 13, 2014, dari Kampanye Simpatik Hari Anti Narkoba Internasional (HANI): http://bemkm.student.uny.ac.id/2013/07/11/kampanyesimpatik-hari-anti-narkoba-internasional-hani/

DPR, D. (2012). Laporan Singkat Delegasi DPR RI KE Sidang Executive Commite (EXCOM) of ASEAN Inter-Parlementary Assembly (AIPA) dan The Ninth Meeting of AIPA Fact Finding Commite (AIFOCOM) To COMBAT THE DRUG MENACE. Yogyakarta: http://www.dpr.go.id/complorgans/inter/lapsing_Laporan_Singkat_Delegasi_ DPR_RI_ke_Sidang_Executive_Committee_of_AIPA_dan_the_9th_Meeting_of_AI FOCOM_pada_tanggal_8-12_Juli_2012_di_DIY_Yogyakarta.pdf.

FORKON. (2011, Januari 31). Kerjasama Bidang Penanggulangan dan Pemberantasan Penyalahgunaan dan Peredaran Gelap Narkotika dan Obat-obat Terlarang (P4GN). Dipetik Februari 22, 2014, dari Indonesia-ASEAN dan Narkotika: http://forumkorbannapza.blogspot.com/2011/01/indonesia-asean-dannarkotika.html 
Garrybaldhi. (2013, Januari 18). Sejarah Madat di Jawa. Dipetik Maret 17, 2014, dari Souvenir From Monaco: http://garrybaldhi.wordpress.com/2013/02/18/sejarah-madat-dijawa/

indomediatv. (2012, Juni 13). Indonesia Tuan Rumah Penyelenggaraan International Drugs Enforcement Conference (IDEC) XXVII. Dipetik Maret 16, 2014, dari itv-chabbel: http://www.itv-channel.com/blog/berita-265-indonesia-tuan-rumahpenyelenggaraan-international-drugs-enforcement-conference-idec-xxvii.html

JIBI. (2013, September 27). Awas, Indekos Kerap Jadi Sasaran Transaksi Narkoba. Dipetik Februari 22, 2014, dari Harianjogja.com: http://www.harianjogja.com/baca/2013/09/27/awas-indekos-kerap-jadisasaran-transaksi-narkoba-451307

Kemlu. (2012, September 21). Hasil Sidang Umum AIPA ke-33. Dipetik Meret 12, 2014, dari http:// kemlu.go.id/Pages/PressRelease.aspx?IDP=1358\&l=idhtml

Kemlu. (2012, April 1). Rangkaian Pertemuan Working Group dan Senior Officials ASEAN di Phnom Penh, Kamboja, 30 Maret-1 April 2012. Dipetik Maret 12, 2014, dari http://www.kemlu.go.id/Pages/PressRelease.aspx?IDP=1318\&l=id

Kompas. (2010, Januari 23). Dideklarasikan, Yogyakarta Zero Narkoba 2015. Dipetik Februari 22 , 2014 dari http://megapolitan.kompas.com/read/2010/01/23/19110642/Dideklarasikan.Yo gyakarta.Zero.Narkoba.2015

Kompas.com. (2008, Desember 19). 3,6 Ton Bahan Narkotika Disita. Dipetik Januari 9, 2014, dari Kompas.com: http://regional.kompas.com/read/2008/12/19/0722398/3.6.Ton.Bahan.Narkotik a.Disita/html

(DPR, 2012). Laporan Singkat Delegasi DPR RI ke Sidang Executive Commite of AIPA dan The 9 Meeting of AIFOCOM. DI Yogyakarta: http://www.dpr.go.id.

Prakoso, Y. (2012, Juli 6). Yogyakarta terkejut akibat peningkatan penggunaan narkoba-Khabar Asia Tenggara. Dipetik Fevruari 22, 2014, dari Yogyakarta terkejut akibat peningkatan penggunaan narkoba: http://khabarsoutheastasia.com/id/articles/apwi/articles/features/2012/07/06 $\angle$ feature-03

Soeharto.co. (2014, Februari 1). Bercermin Pada KanjengGusti Mangkunegoro. Dipetik Maret 14, 2014, dari http:// soeharto.co/becermin-pada-kanjeng-gusti-mangkunegara

Sujatmiko, T. (2013, Juni 26). 2014, Pengguna Narkoba DIY Tembus 97.432 Orang. Dipetik Februari 22, 2014, dari KRjogja.com: http://krjogja.com/read/177964/2014pengguna-narkoba-diy-tembus-97432-orang.kr

Sunartono. (2013, Desember 18). Satgas Anti Narkoba Dikukuhkan Dari Dalam Lapas Narkotika. Dipetik Februari 14, 2014, dari harianjogja.com: http://www.harianjogja.com/baca/2013/12/18/satgas-anti-narkobadikukuhkan-dari-dalam-lapas-narkotika-475620

Tribun. (2013, Juni 12). Napi Cipinang Kendalikan Pabrik Pembuatan Ekstasi di Kalideres. Dipetik Januari 9, 2014, dari Tribunnews.com: http://www.tribunnews.com/metropolitan/2013/06/12/napi-cipinangkendalikan-pabrik-pembuatan-ekstasi-di-kalideres 